\title{
THE ACCOMPANYING FAUNA \\ OF SOLITARY BEE OSMIA BICORNIS (L.) SYN. OSMIA RUFA (L.) NESTS SETTLED IN DIFFERENT BIOTOPES
}

\author{
Monika Fliszkiewicz, Anna Kuśnierczak, Bożena Szymaś \\ Department of Apidology, Institute of Zoology, Poznań University of Life \\ Sciences, Wojska Polskiego 71C, 60-625 Poznań, Poland. \\ e-mail: monef@up.poznan.pl
}

Received 08 November 2011; accepted 24 April 2012

$\mathrm{S}$ u m m a r y

\begin{abstract}
Red mason bee Osmia bicornis (L.) is a solitary bee which has been shown to be a successful pollinator of many field crops and greenhouse crops. In favorable environmental conditions, this solitary bee can significantly raise the efficiency of crops. Controlled honeybee farms are invaded by various accompanying fauna. The aim of the study was to find out if the biotope may increase or limit the presence of foreign fauna in the nests of the solitary bee $O$. bicornis (L.). Four different biotopes were selected: a traditional orchard, the dendrological park of the Polish Academy of Sciences in Kórnik, a mixed forest, and a haymeadow, where artificial aggregations of $O$. bicornis (L.) were made, with 300 specimens in each. They were given artificial nests of common reed. The nests were then analysed after the end of the brooding period. The number of brood chambers built by females was determined. The number of chambers where the forms of development stopped at the egg or larva stage, the number of parasite-invaded chambers, and the systematic membership of the encountered foreign fauna, was also determined. The analysis of variance and Duncan's test with the significance level of $\alpha=0.05$ proved that the biotope influenced the development of the O. bicornis (L.) population. The females in the forest biotope built the most brood chambers in each tube on average, and the result was significantly different from the other biotopes. The largest number of larvae died in the nests which had been placed in the dendrological park, and that value was also statistically different from the others. The highest parasite invasion was noted in the nests situated in the forest.
\end{abstract}

Keywords: Osmia bicornis (L.), Osmia rufa (L.), biotope, parasites, associated fauna.

\section{INTRODUCTION}

Solitary bees, including Osmia bicornis (L.), are a significant supplementary factor for good pollination of plants (Bosch and Kemp, 2002). With the continuously decreasing population of honeybees nowadays, solitary bees continue to contribute to the increased yield of seeds and fruit of many plants (Torchio, 1991b; Kemp, 2000; Monzón et al., 2004; Komissar, 2005). Controlled breeding of the solitary bee is invaded by various fauna, including parasitopids, cleptoparasites, and predators (Krunić et al., 2005). After some time, the influence of the harmful accompanying fauna may weaken or even destroy some aggregations of solitary bees. For this reason, it is recommended that measures be taken to eradicate parasites.

In natural aggregations of solitary bees it is possible to notice the harmful activity of parasites, commensals, kleptoparasites and other associated entomofauna in the nests of many species of Osmia (Wójtowski and Szymaś, 1973; Wójtowski et al., 1991; Krunić et al., 2005). Goodell (2003) posed the hypothesized that limitation of a food base may reduce the reproductive success of bred bees and intensify the risk of predation or parasitism.

The aim of our study was to find out if the biotope increases or limits the presence of foreign fauna in solitary bee O. bicornis (L.) nests. 


\section{MATERIAL AND METHODS}

In order to test whether the environment may influence the increase or limitation of parasitical and associated entomofauna in O. bicornis (L.) nests, four different biotopes were selected. The biotypes were located within the community of Kórnik (52,238N;17,095E), District of Poznań, Poland. It was the first time $O$. bicornis (L.) was bred in the selected biotopes.

The four biotopes were: a traditional orchard, the dendrological park of the Polish Academy of Sciences in Kórnik [Arboretum], a mixed forest, and a haymeadow. All the biotypes were located $8 \mathrm{~km}$ away from each another. Three brood nest containers as field shelter for O. bicornis (L.), were placed in each of the biotypes (Wójtowski et al., 1991). The containers were located on 0.5 ha in each of the biotopes. Sunny spots in the centre rather than at the edge of the area were chosen. The field shelters were placed on stands, about $1.5 \mathrm{~m}$ above the ground. Each field shelter contained four artificial nests made of common reed (Phragmites australis (Cav.) Trin. ex Steud.) cut into pieces $18 \mathrm{~cm}$ in length. The diameter of the reed tubes fluctuated from 6 to $9 \mathrm{~mm}$. There were about 80 empty tubes in one nest. In each research spot, artificial aggregations of $O$. bicornis (L.) were made with 300 specimens: 150 females and 150 males in cocoons. The sex was determined by the size and location of cocoons in the nest tubes (Raw and O'Toole, 1979). The nests from which the cocoons were collected came from the own breeding of the Department of Apidology, Institute of Zoology, Poznan University of Life Sciences. This department has a long history of experience, and is located in the orchards of the Przybroda Agricultural and Orchard Experimental Farm. The cocoons were placed in cardboard incubators (Wójtowski et al., 1991) in the field shelter, directly on empty artificial nests, 10 days before the due hatching of imagines. The hatching took place in late April and early May, in the research year 2010.
Honey plants in each ecosystem were inventoried within about $500 \mathrm{~m}$ from the field shelter. Also, the average daily temperature, cloudiness, and precipitation were noted during the experiment.

After finishing the total development of a first filial generation (November), the settled nests were analysed. The number of brood chambers (cells) built by females was determined as well as the number of chambers where the forms of development stopped at the egg or larva stage. The number of parasite-invaded chambers and the systematic membership of the encountered foreign fauna was determined.

In order to determine if there were differences in the number of brood chambers built by the females and in the number of dead larvae per nest tube, a one-way analysis of variance was done for the mean values of the characteristics in question. In order to determine which of the characteristics under investigation had significantly different mean values, Duncan's test was performed, where the probability was 0.05 . The calculations were made with the package Statgraph 4.0. For better visualisation, the results were presented in tables, where the same small letters meant the absence of significant differences.

\section{RESULTS}

Table 1 shows the biotope characteristics. There were similar weather conditions in all the biotopes during the experiment. Table 2 shows mean temperatures, precipitation, and cloudiness during bee activity.

There were unfavourable weather conditions to the reproduction of the O. bicornis (L.) (Tab. 2). A particularly large number of rainy days in May caused less intensive flights of females. The result was a smaller number of brood chambers built in the nests (Tab. 3).

Table 3 shows the results of the analysis of settled nests in individual biotopes.

The highest average number of brood chambers (6.59) in each settled tube was in the meadow, biotope (2). It differed significantly from all the other biotopes 
The biotope characteristics

\begin{tabular}{|c|c|c|}
\hline Biotope & Area characteristics & Flora \\
\hline $\begin{array}{l}\text { Arboretum } \\
\text { (1) }\end{array}$ & $\begin{array}{l}\text { The arboretum of the Institute of } \\
\text { Dendrology, Polish Academy of } \\
\text { Sciences contains a wide collection } \\
\text { of woody plants and bushes } \\
\text { from the temperate zone of the } \\
\text { northern hemisphere (Europe, } \\
\text { Asia, North America) on } 50 \text { ha. }\end{array}$ & $\begin{array}{l}\text { Cotoneaster lucidus (Schltdl.), Viburnum fragrans (Bunge), } \\
\text { Viburnum Sieboldiil (Miq.), Syringa vulgaris (L.), } \\
\text { Syringa meyeri (Palibin), Azalea pontica (L.), } \\
\text { Rhododendron sp. (L.), Eranthis hymealis (L.), } \\
\text { Fagus sylvatica (L.), Betula (L.) sp., Quercus (L.) sp., } \\
\text { Tilia (L.) sp., Aesculus hippocastanum (L.), Cerasus } \\
\text { (Miller) sp., Myosotis arvensis (L.), Laburmum (Fabr.)sp., } \\
\text { Ranunculus acer (L.), Magnolia acuminata (L.), } \\
\text { Magnoliax soulangeana.(Soul-Bod.) }\end{array}$ \\
\hline $\begin{array}{l}\text { Meadow } \\
\text { (2) }\end{array}$ & $\begin{array}{l}\text { Semi-natural haymeadow in } \\
\text { the second year of use }\end{array}$ & $\begin{array}{c}\text { Ranunculus acris (L.), Taraxacum officinale (L.), } \\
\text { Lychnis flos-cuculi (L.), Leucanthemum vulgare (Lam.), } \\
\text { Knautia arvensis (L.), Leontodon hispidus (L.), } \\
\text { Tragopogon pratensis (L.), Vicia cracca (L.), } \\
\text { Daucus carota (L.), Urtica dioica (L.), Campanula patula (L.), } \\
\text { Myosotis arvensis (L.), Trifolium repens (L.), } \\
\text { Trifolium pratense (L.), Cardamine pratensis (L.), } \\
\text { Bellis perennis (L.) }\end{array}$ \\
\hline $\begin{array}{l}\text { Forest } \\
\text { (3) }\end{array}$ & $\begin{array}{l}\text { - Mixed forest mostly with } \\
\text { coniferous trees; chiefly pines } \\
\text { - Relatively numerous bushes in } \\
\text { lower layers, herbaceous plants } \\
\text { in understory and groundcover }\end{array}$ & $\begin{array}{l}\text { Pinus (L.) sp., Picea (Dietr) sp., Abies (Mill.) sp., Fagus } \\
\text { (L.) sp., Betula (L.) sp., Quercus (L.) sp., Populus (L.) } \\
\text { sp., Frangula alnus (Mill.), Euonymus (L.) sp., Corylus } \\
\text { (L.) sp, Rubus fruticosus (L.), Hypericum perforat (L.), } \\
\text { Convalaris silvestris (L.), Hierocilum murorum (L.), } \\
\text { Scorzonera humilis (L.), Oxalis acetosella (L.) }\end{array}$ \\
\hline $\begin{array}{l}\text { Orchard } \\
\text { (4) }\end{array}$ & $\begin{array}{l}\text { - Trees planted in five rows, each } \\
200 \text { m long (about } 0.5 \text { ha) } \\
\text { - Lawn grown between trees. }\end{array}$ & $\begin{array}{l}\text { Trees: Persica vulgaris (L.) aged } 12 \text { years, } \\
\text { Prunus domestica (L.) aged } 2 \text { years and } \\
\text { Cerasus vulgaris (Mill.) aged } 8 \text { years. }\end{array}$ \\
\hline
\end{tabular}

Table 2 .

The weather conditions during the experiment

\begin{tabular}{||c|c|c|c||}
\hline Period of observation & $\begin{array}{c}\text { Mean daily } \\
\text { temperature }\left({ }^{\circ} \mathrm{C}\right)\end{array}$ & $\begin{array}{c}\text { Number of days } \\
\text { with rainfall }\end{array}$ & $\begin{array}{c}\text { Number of } \\
\text { cloudy days }\end{array}$ \\
\hline 1-31 May 2010 & 18 & 22 & 5 \\
\hline 1-30 June 2010 & 22 & 6 & 19 \\
\hline 1-10 July 2010 & 27 & 1 & 7 \\
\hline
\end{tabular}

Table 3 .

The average number of brood chambers built and dead larvae of $O$. bicornis (L.) per nest tube in individual biotopes

\begin{tabular}{||l|l|l||}
\hline \multicolumn{1}{|c|}{ Biotope } & $\begin{array}{l}\text { Brood chambers } \\
\text { per tube }\end{array}$ & \multicolumn{1}{c|}{$\begin{array}{c}\text { Dead Osmia } \\
\text { bicornis larvae }\end{array}$} \\
\hline Arboretum (1) & $6.05 \mathrm{a}$ & $3.06 \mathrm{a}$ \\
\hline Meadow (2) & $6.59 \mathrm{~b}$ & $1.19 \mathrm{~b}$ \\
\hline Forest (3) & $5.83 \mathrm{a}$ & $0.98 \mathrm{c}$ \\
\hline Orchard (4) & $5.83 \mathrm{a}$ & $1.11 \mathrm{bc}$ \\
\hline
\end{tabular}

* different letters indicate significant differences at $\alpha=0.05$.

(Tab. 3). The highest larva mortality was noted in the dendrological park (1). On average, the dendrological park larva mortality was as high as 3.06 in each tube and it was significantly different from the other three biotopes. The fewest larvae died in the tubes placed in the forest (3) (0.98).
Table 4 shows the total number of settled and empty brood chambers and the percentage of chambers invaded by harmful and associated fauna in individual biotopes. 
The degree of parasitical invasion of brood chambers in individual biotopes

\begin{tabular}{||c|c|c||}
\hline Biotope & $\begin{array}{c}\text { Total number of } \\
\text { brood chambers }\end{array}$ & $\begin{array}{c}\text { Chambers invaded by harmful } \\
\text { and associated fauna in total } \\
\text { number of settled brood chambers } \\
(\%)\end{array}$ \\
\hline Arboretum (1) & 3149 & $(1.1) \mathrm{a}$ \\
\hline Meadow (2) & 4639 & $(5.9) \mathrm{b}$ \\
\hline Forest (3) & 2435 & $(9.5) \mathrm{c}$ \\
\hline Orchard (4) & 3644 & $(2.4) \mathrm{a}$ \\
\hline
\end{tabular}

* Identical small letters refer to insignificant differences, where $\alpha=0.05$.

The females built different total numbers of brood chambers in the nest tubes at the biotopes under investigation. The highest number was noted in the meadow (2) and the lowest - in the forest (3). An intermediate number of chambers was noted in the nests situated in the orchard (4) and in the arboretum (1) (Tab. 4).

The highest percentage of parasite invasion was noted in the forest (3). It was significantly different from all the others. The second most invaded biotope was the meadow (2) which also differed significantly from the other three biotopes. On the other hand, in the dendrological park (1) and orchard (4), the percentage of chambers invaded by parasites did not differ from each other but were different from those of the meadow and forest (3) (Tab. 4).

When the species composition of the parasites found in the brood chambers was determined, it turned out that in all four biotopes, the insects from the following orders had the highest share: from Hymenoptera: Chrysis ignita (L.), Monodontomerus obscurus (West.), and Sapyga quinguepunctata (Fab.); and from Diptera: Hemipenthes morio (L.), Anthrax anthrax (Sch.) and Cacoxenus indagator Loew. The number of species of foreign fauna was not determined.

\section{DISCUSSION}

At present the methods of breeding bees from the Megachilidae family are well-known. These methods are applied in many countries all over the world (Wójtowski, 1971; Raw, 1972;
Parker et al., 1987; Torchio, 1991a; Bosch, 1994; Delaplane and Mayer, 2000; Kemp, 2000; Krunić and Stanis avljević, 2006). Bees of the Genus Osmia, for example Osmia cornifrons (Rad.), are used especially for pollination of orchard crops in Japan (Maeta, 1978; Sekita, 2001), but Osmia lignaria (L.) bees are also used in the United States (Torchio, 1976; Bosch and Kemp, 2001). In Germany and in the United Kingdom (Raw, 1972) Osmia bicornis (L.) (Holm, 1973; Krisátjansson, 1989) is used. In Spain (Bosch, 1994) and Serbia (Krunić et al., 1995, 2005) Osmia cornuta (Latr.) is used. In Poland Osmia rufa (L.) syn. Osmia bicornis (L.) (Wójtowski et al., 1991; Wilkaniec, 1990; ZientekVarga, 2006) is used. The use of other bees than honeybees for pollination of crops is one of the alternative methods of satisfying the needs of plant pollination as well as future needs (Torchio, 1991b).

In all the biotopes, the average number of brood chambers per one settled reed tube was the same as in the results provided by other authors (Wójtowski and Wilkaniec, 1969; Wilkaniec et al., 2000; Bąk and Wilde, 2003, 2005), who reported about 6-8 brood chambers in one tube. The length and diameter of the tubes used in our experiment are similar to those of other authors. The results of this study fluctuated around the lower limit, though, and amounted to 5.8-6.5 brood chambers in one tube. This may have been caused by a large number of rainy days in May and, as a consequence, worse flights of Osmia females in the aggregations. The largest 
number of brood chambers was built in the nests placed in the meadow biotope. This was due to the more favourable and more diversified composition of plant species, which were the food base for bees in the biotope. On the other hand, the O. bicornis (L.) females reproducing in biotope 3 (forest) and biotope 4 (orchard), built the fewest brood chambers - the average value was 5.83 chambers in each settled tube. No statistically significant differences between those two biotopes and biotope 1 (arboretum) were proved, where the O. bicornis (L.) females on average built 6.05 chambers in each settled nest.

The observed high larva mortality in the arboretum biotope may have been caused by the $O$. bicornis (L.) females having access to the toxic pollen of widely blooming plants in several hectares of the dendrological park. The pollen of the following plants, fell within the flight range of our bees, and is toxic to bees: Thymelaeaceae (Juss.), Rhododendron (L.), Laburnum (Fabr.), and Aesculus (L.) (Palmer - Jones, 1964; Ott, 1998; Gliński et al., 2006). However, a palynological analysis of pollen stores in nest tubes was not performed. For this reason, we can only speculate on the possible impact of the above mentioned plants on the survival of larvae.

The harmful effect of parasites in big bee aggregations was noted by Wójtowski and Szymaś (1973), and Szymaś (1991), especially in the controlled bee farms of Wójtowski and Wilkaniec (1969). The highest invasion of foreign fauna in brood chambers was found in the nests located in the forest biotope. According to Goodell (2003), limited access to the food base may affect the reproductive success and intensify parasitism, which probably was also true in our experiment. Of the foreign fauna, the following species of kleptoparasites commonly found on the European continent were noted: Cacoxenus indagator Loew (Diptera, Drosophilidae), and Chrysis ignita L. (Hymenoptera,
Chrysididae). The observed parasitoids were: Monodontomerus obscurus Westwood (Hymenoptera, Torymidae), Hemipenthes morio L. (Diptera, Bombyliidae), Sapyga quinqepunctata F. (Hymenoptera, Sapygidae) and Antrax antrax Sch. (Diptera, Bombyliidae). All of them were confirmed by many authors in the studies analysing the parasitical and associated fauna of the nests of different solitary bee species (Linsley, 1958; Eves, 1970; Wójtowski and Szymaś, 1973; Eves et al., 1980; Szymaś, 1991; Bosch, 1992; Felicioli and Pinzauti, 1998; Krunić et al., 2005).

\section{CONCLUSION}

1. The biotope type was found to influence the degree of fauna invasion of solitary bee $O$. bicornis (L.) nests.

2. The most brood cells were built in the nests situated in the meadow biotope, whereas the least - in the forest biotope.

3. The most brood chambers invaded by foreign fauna were observed in the nests situated in the forest biotope, whereas the least - in the dendrological park and orchard.

4. The highest percentage of dead larvae was found in the dendrological park biotope. This might have been caused by the toxicity of some plants' pollen to the larvae.

\section{REFERENCES}

Bąk B., Wilde J. (2003) - Tempo rozwoju populacji murarki ogrodowej - Osmia rufa (L.) (Hymenoptera: Apidae) w sztucznych gniazdach trzcinowych. [Developmental rate of garden mason bee, Osmia rufa L. population in artificial Reed nests - in Polish]. Wiadomości Entomologiczne, 22: 161-167.

Bąk B., Wilde J. (2005) - Amatorski chów murarki ogrodowej (Osmia rufa L.). [Rearing Osmia rufa L. as an amateur systems - in Polish]. Pszczelarstwo, 6: 2-4.

Bosch J. (1992) - Parasitism in wild and managed populations of the almond pollinator Osmia cornuta (Latr.) (Hymenoptera, Megachilidae). J. Apic. Res., 31(2): 83-95. 
Bosch J. (1994) - Improvement of field management of Osmia cornuta (Latreille) (Hymenoptera, Megachilidae) to pollinate almond. Apidologie, 25: 71-83.

Bosch J., Kemp W. (2001) - How to manage the blue orchard bee as orchard pollinator.Sustainable Agriculture Network National Agricultural Library, Beltsville, MD, USA.

Bosch J., Kemp W. P. (2002) - Developing and establishing bee species as crop pollinators: the example of Osmia spp. (Hymenoptera: Megachilidae) and fruit trees. Bull. Entomol. Res., 92: 3-16, Pub Med, CSA.

Delaplane K. S., Mayer D. F. (2000) - Crop Pollination by Bees. Wallingford: CABI Publishing.

Eves J. D. (1970) - Biology of Monodontomerus obscurus Westwood, a parasite of the Alfalfa Leafcutting bee Megachile rotundata (Fabricius) (Hymenoptera: Torymidae; Megachilidae) - Melanderia. 4: 1-18.

Eves D. J., Mayer F. D., Johansen A. C. (1980) - Parasites, predators, and nest destroyers of the alfalfa leafcutting bee, Megachile rotundata. A Western Regional Extension Publication, Washington State.

Felicioli A.,Pinzauti M.(1998) - The impact of the solitary bee parasite Antrax antrax Schrank (Diptera, Bombyliidae) on a wild population of the mason bee Osmia cornuta Latr. (Hymenoptera, Megachilidae), In: Fourth International Congress of Dipterology, Abstracts Volume, Keble College, Oxford, UK.

Gliński Z., Kostro K., Luft-Deptuła D. (2006) - W: Choroby pszczół. [Illness honeybee - in Polish]. PWRiL Warsaw.

Goodel K. (2003) - Food availability affects Osmia pumila (Hymenoptera: Megachilidae) foraging, reproduction, and brood parasitism. Oecologia, 134, 4: 518-527.

Holm S. N. (1973) - Osmia rufa L. (Hymenoptera) as a pollinator of plants in greenhouses. Entomol. Scand., 4, 3: 217-223.

Kemp W. P. (2000) - The future of crop pollination. Am. Bee. J., 140, 11: 851-853.

Komissar A., (2005) - Rearing Osmia bees in Ukraine. The Beekeepers Quarterly, 82: 41-42.
Kristjánsson K. (1989) - Investigations on the possibilities of using the solitary bee Osmia rufa L. as a pollinator in Denmark. 146 p., Doctoral thesis, Department of Crop Science, University Copenhagen, Denmark.

Krunić, M., Pinzauti, M., Felicioli, A., Stanisavljević, Lj. (1995) - Further observations on Osmia cornuta (Latr.) and O. rufa (L.) as alternative fruit pollinators, domestication and utilization. Archives of Bioogical Science, Belgrade, 47(1-2), 59-66.

Krunić M., Stanislavljević L., Pinzauti M., Felicioli A. (2005) - The accompanying fauna of Osmia cornuta and Osmia rufa and effective measures of protection. Bullet. Insec., 58(2): 141-152.

Krunić, M., Stanisavljević, Lj. (2006) - Augmentation of managed populations of Osmia cornuta (Latr.) and O. rufa (L.) (Hymenoptera: Megachilidae) in Southeastern Europe. Eur. J. Entomol., 103(3): 695697.

Linsley G. E. (1958) - The ecology of solitary bees. Hilgardia, 27(19): 543-599.

Maeta Y. (1978) - Comparative Studies on the Biology of the Bees of the Genus Osmia of Japan, with Special Reference to Their Managements for Pollinations of Crops (Hymenoptera: Megachilidae). Bull. Tohoku Nat. Agricult. Exp. St., 57: 1-221.

Monzón V. H., Bosch J., Retana J. (2004) - Foraging behavior and pollinating effectiveness of Osmia cornuta (Hymenoptera: Megachilidae) and Apis mellifera (Hymenoptera: Apidae) on "Comice" pear. Apidologie, 35(6): 575-585.

Ott J. (1998) - The delphic bee: bees and toxic honeys as pointers to psychoactive and other medicinal plants. Econ. Bot., 52(3): 260-266.

Palmer-Jones T. (1964) - Poisonous Honey overseas and in New Zealand. N. Z. M. J., 64: 631-637.

Parker F. D., Batra S. W. T., Tepedino V. J. (1987) - New pollinators for our crops. Agric. Zool. Rev., 2: 279-304.

Raw A. (1972) - The biology of the solitary bee Osmia rufa (L.) (Megachilidae). Trans. $R$. Entomol. Soc. Lond., 124: 213-229. 
Raw A., O'Toole C. (1979) - Errors in Sex of Eggs laid by the solitary bee Osmia rufa (Megachilidae). Behaviour, 70(1-2): 168-171.

Sekita N. (2001) - Managing Osmia cornifrons to pollinate apples in Aomori Prefecture, Japan. Acta Horticulturae, 561: 303-307.

Szymaś B. (1991) - Entomofauna pasożytnicza czynnikiem ograniczającym populacje pszczół samotnie żyjących (Apidae solitariae). [Parasitic entomofauna as a factor li miting the population of solitary bees - in Polish]. Przeglad Zoologiczny, XXXV (3-4): 307-313.

Torchio P. F. (1991a) - Use of Osmia lignaria propinqua (Hymenoptera: Megachilidae) as a mobile pollinator of orchard crops. Environ. Entomol., 20: 590-596.

Torchio P.F. (1991b) - Bees as crop pollinators and the role of solitary species in changing environments. Acta Horticulture, 288: 49-61.

Torchio P. F. (1976) - Use of Osmia lignaria Say (Hymenoptera: Apoidea, Megachilidae) as a pollinator in an apple and prune orchard. J. Kans. Entomol. Soc., 49(4): 475-482.

Wilkaniec Z. (1990) - Intensywność i efektywność oblotu jabłoni przez owady zapylające $\mathrm{w}$ zależności od formy korony $\mathrm{i}$ odmiany. [Intensity and efectivness of flights on Apple trees by pollinating insects depending on form of tree crown - in Polish]. Rocz. AR w Poznaniu, 207 (Rozprawy naukowe).

Wilkaniec Z., Giejdasz K., Fliszkiewicz M. (2000) - Effect of differentiated nest tubes on their settlement by the solitary bee Osmia rufa L. (Megachilidae). Pszczel. Zesz. Nauk., 44(2): 311-317.
Wójtowski F. (1971) - Bioekologiczne i techniczne problemy hodowli i praktycznego użytkowania pszczół samotnic. [Bioecologist and technical problems rearing to make use of practical solitary bee - in Polish]. Wiadomości Ekologiczne, 17(1): 53-58.

Wójtowski F. (1983) - Pszczoła murarka ogrodowa chów i użytkowanie. [The red mason bee breeading and use of practical - in Polish]. AR w Poznaniu, Zakład Upowszechniania Postępu w Rolnictwie. PWRiL, Poznań.

Wójtowski F., Wilkaniec Z. (1969) Próby hodowli pszczół miesiarek i murarek (Hymenoptera, Apoidea, Megachilidae) w pułapkach gniazdowych. [Attempts to rearing Alfalfa Leafcutting Bees and Orchard Mason Bees at nest traps - in Polish]. Roczniki Wyższej Szkoty Rolniczej w Poznaniu, XLII.

Wójtowski F., Wilkaniec Z., Szymaś B. (1991) - Próby reintrodukcji wybranych gatunków pszczołowatych (Apoidea) w warunkach intensywnej gospodarki rolnej. [Reintroduction trals of selected bee species (Apoidea) In conditions of intensive agricultural economy - in Polish]. Rocz. AR w Poznaniu, 229: 181-192.

Wójtowski F., Szymaś B. (1973) Entomofauna pasożytnicza i towarzysząca pszczołom samotnym (Apoidea Solitariae) w pułapkach gniazdowych. [Parasitic entomofauna and nest traps accompanying solitary bees (Apoidea solitaeriae) - in Polish]. Rocz. AR w Poznaniu, 46: 171- 179.

Zientek-Varga J. (2006) - Tajemnice dzikich pszczół - zapyla i muruje. [The secrets solitary bee - pollinate and construct - in Polish]. Przyroda Polska, 5: 12-13. 


\title{
FAUNA TOWARZYSZĄCA I PASOŻYTNICZA GNIAZD PSZCZOLY SAMOTNICZEJ OSMIA BICORNIS (L.) SYN. OSMIA RUFA (L.), ZASIEDLONYCH W RÓŻNYCH BIOTOPACH
}

\author{
Fliszkiewicz M., Kuśnierczak A., Szymaś B. \\ S t r e s z c z e n i e
}

Osmia bicornis (L.) podobnie jak inne pszczoły samotnicze, stanowi poważny czynnik uzupełniający w stosunku do pszczoły miodnej, umożliwiający dobre zapylenie roślin. Kontrolowane hodowle pszczół samotnych w znacznym stopniu opanowywane są przez różną faunę towarzyszącą i pasożytniczą. Celem pracy było stwierdzenie, czy biotop może zwiększać bądź ograniczać występowanie fauny obcej w gniazdach pszczoły samotniczej $O$. bicornis (L.). Wybrano 4 różne biotopy: sad tradycyjny, park dendrologiczny PAN w Kórniku, las mieszany, łąka kośna, w których utworzono sztuczne agregacje murarki ogrodowej O. bicornis (L.) liczące po 300 osobników. Udostępniono im sztuczne gniazda z trzciny pospolitej, które poddano analizie po zakończonym okresie rozrodczym. Określono liczbę zbudowanych przez samice komór lęgowych, liczbę komór, w których zamarły formy rozwojowe w stadium jaja bądź larwy, liczbę komór spasożytowanych, a także określono przynależność systematyczną spotkanej fauny obcej. Przeprowadzona analiza wariancji oraz test Duncana na poziomie istotności $\alpha=0,05$, wykazały że biotop miał wpływ na rozwój populacji murarki ogrodowej. Najwięcej komór lęgowych średnio w każdej rurce, zbudowały samice w biotopie las i wynik ten był istotnie różny w stosunku do pozostałych biotopów. Natomiast najwięcej larw zamarło $\mathrm{w}$ gniazdach wystawionych w parku dendrologicznym i również ta wartość różniła się statystycznie w stosunku do pozostałych. Najwyższe spasożytowanie komór odnotowano w gniazdach usytuowanych w lesie.

Słowa kluczowe: Osmia bicornis (L.), Osmia rufa (L.), biotop, pasożyty, fauna towarzysząca. 